\title{
Pain management for cancer survivors
}

\author{
Mizuho Sumitani ${ }^{1}$, Jun Hozumi ${ }^{2}$, Hiroaki Abe ${ }^{2}$ Yaeko Yokoshima $^{2}$, Rikuhei Tsuchida ${ }^{2}$, \\ Kazuhito Mietani $^{2}$ and Masahiko Sumitani ${ }^{3}$
}

\begin{abstract}
1 慶友銀座クリニック， ₹ 104-0045 東京都中央区築地 1-13-11-201 (Department of Otorhinolaryngology, Keiyu Ginza Clinic, 1-13-11-201 Tsukiji, Chuo-ku, Tokyo 104-0045, Japan)

${ }^{2}$ 東京大学医学部附属病院麻酔科・痛みセンター, ₹ 113-0033 東京都文京区本郷 7-3-1 (Department of Anesthesiology and Pain Relief Center, The University of Tokyo Hospital, 7-3-1 Hongo, Bunkyo-ku, Tokyo 113-0033, Japan)

3 東京大学医学部附属病院緩和ケア診療部, ₹ 113-0033 東京都文京区本郷 7-3-1 (Department of Pain and Palliative Medicine, The University of Tokyo Hospital, 7-3-1 Hongo, Bunkyo-ku, Tokyo 113-0033, Japan)
\end{abstract}

Received: October 31, 2017 / Accepted: January 16, 2018

\begin{abstract}
From the start, World Health Organization has proposed that palliative medicine is applicable early in the course of illness. However, regrettably, palliative care has been usually provided to patients in the advanced cancer stage, as a terminal care. Recently, palliative medicine begins at the time-point when patients are diagnosed with cancer. In response to change in clinical settings of palliative medicine, cancer pain management has also changed. Considering long-term cancer treatment periods and increasing numbers of cancer survivors, cancer pain management should be recommended based on not only non-opioid pharmacotherapy but also the exercise/rehabilitation medicine and the cognitive-behavioral therapy. Especially, the exercise/rehabilitation medicine can provide beneficial effects on both pain management and cancer treatment itself: Sarcopenia is closely associated with poor prognosis of cancer and debilitating complications of chemotherapy. Further, non-sarcopenia patients can maintain their quality of life higher and show less fatigue during cancer treatment periods. To accomplish such favorable effects for cancer patients and cancer survivors, cancer pain should be managed adequately.
\end{abstract}

Jpn J Phys Fitness Sports Med, 67(2): 157-163 (2018)

Keywords : cancer pain, palliative care, cancer survivor, sarcopenia

\section{はじめに}

生命予後が 2 週間以内の臨死状態にあるがん患者のほ ぼ全員が全身僚怠感掞よび食欲不振を訴え, 約 $80 \%$ の患 者が痛みを訴える。さらに70 80\%が便秘，睡眠障害， 呼吸困難を訴えている。これらの身体的および精神心理 的問題点のうち, 痛み以外の問題は臨死 45 日前の時点で は25\%以下の患者が訴えるに留まっている。一方，痛み については, 臨死 90 日前の時点で既に約 $40 \%$ の患者が 中等度以上の痛みを訴えて扔り, 痛みはがん進行・終末 期の最も早い時期から出現し, 臨死の直前まで問題とし て持続することが多い.1982年当時，このようながん 患者の痛みへの対策が不十分であるとして世界保健機 関（WHO）が，がん性疼痛治療ガイドライン「Cancer Pain Relief（がんの痛みからの解放）」を発刊し， 3 段階 鎮痛ラダー（Fig. 1) を世界に向けて提案した。このガイ ドラインでは，痛みの重症度を評価するとともに鎮痛薬
を段階的に使用する治療戦略は世界中で広く受け入れら れ，オピオイド鎮痛薬（医療用麻薬）に対する過剩な警 戒心の払拭に貢献するとともに，がん性疼痛患者のがん 患者の疼痛管理の質は飛躍的に向上した。疼痛はQuality of Life（QOL）の重大な阻害因子であるため, 実際, がん性疼痛治療の成功はがん患者の QOLを大きく改善 することができた ${ }^{1,2)}$ 。この 3 段階鎮痛ラダーの普及は, 本邦でも終末期がん性疼痛患者にとって大きな福音と なったことは言うまでもないが，残念なことにがん性疼 痛 (cancer pain) という用語が“がん自体による疼痛 (pain by cancer itself)”とだけ認識された結果，がん浸潤や 転移に伴う痛みがある患者は一般にがん進行期であるた め, 緩和医療が終末期医療として提供されることが通例 となってしまった。

しかしながら，2000年代に入り，WHOが1982年当初 から「緩和医療は疾患の経過の早期から提供されるべき」 とした文言が見直され始め，がん性疼痛という用語の範 


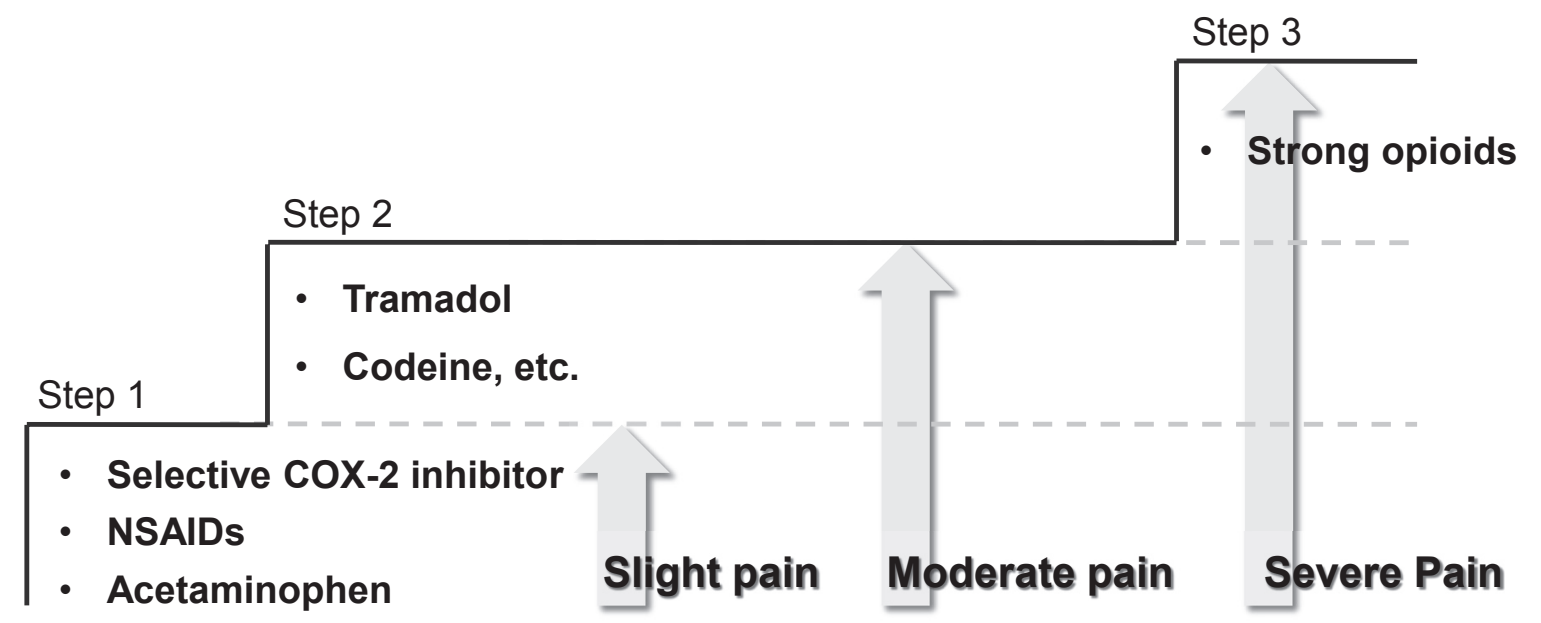

Fig. 13 -step analgesic ladder proposed by the World Health Organization From the start of cancer diagnosis, the World Health Organization has proposed that palliative medicine is applicable early in the course of illness. Cancer pain (i.e., pain by cancer itself and cancer treatment-related pain) should be adequately managed by pharmacotherapy with a step-wise manner.

疇に“がん自体による痛み”だけでなく“がん治療に伴 う痛み (cancer treatment-related pain)” も含めて考え るようになってきており, 厚生労働省および緩和医療学 会は「がんと診断されたときからの緩和ケア」という キャッチフレーズを提唱し，非終末期医療としての緩和 医療の普及に努めている。実際，がん患者では診断初期 から 20〜25\%の患者が鎮痛薬を要する痛みを訴えてお り,さらに診断から 1 年時点でも 25〜30\%は鎮痛薬を 使用している ${ }^{3)}$. 本邦でも同様に，がん根治的治療期の 患者の約 $20 \%$ の患者が痛みを訴え, さらに，がん支持 療法期になると痛みを訴える患者の割合は30-40\%に増 加することが示されている (平成 15 年度厚生労働科学 研究費補助金医薬安全総合研究事業「がん疼痛治療にお けるオピオイド鎮痛薬の適正使用に関する研究」調査). このような痛みはがん自体による痛みというよりはがん 治療に伴う痛みであることが想定され，緩和ケアをがん 治療期から導入する方針が徐々に浸透しつつあり，がん 性疼痛には a ）がん終末期の痛みとb）がん治療期の痛 みの総称であることが総論的に理解されている.

がん治療の進歩により, がん生命予後の議論は 5 年生 存率から 10 年生存率に拡大し, 乳がんに至っては 10 年 生存率から 20 年生存率が当たり前に議論されるように なってきた。このようながん治療の成績の向上は, がん 治療期間の長期化とキャンサーサバイバー（がん長期生 存者）の増加を意味しており，がん患者の抱える痛みへ の対策も大きな変換を迎えている.

\section{がん患者の痛み対策 - 病態と薬物療法}

がん患者の疼痛対策において最も標準的な治療法は薬
物療法である。薬物療法は痛みの病態 (発症メカニズム) に応じて鎮痛効果が異なるため，薬剤選択のためにまず 痛みの病態を評価することが重要である（Fig. 2).

侵害受容性（炎症性）疼痛=終末期がん内臓痛, がん骨 転移痛, がん術後急性痛, がん放射線治療による皮膚炎 や口腔粘膜炎, 化学療法誘発性口腔粘膜炎 未梢組織中 に存在する末梢神経終末上の侵害受容器が興奮した際に 起こる疼痛を侵害受容性疼痛という。組織の炎症に伴う 痛み（炎症性疼痛）も侵害受容性疼痛に含まれる。侵害 受容性/炎症性疼痛は生理的には生体を防御する警告系 として存在するが, がん自体による痛みとがん治療に 伴う痛みのいずれもQOLを著しく低下させる。がん性 侵害受容性疼痛にはがんが内臓や骨転移した際の痛み 以外に，がん治療に伴う術後急性痛などが挙げられる。 一般に非ステロイド性消炎鎮痛薬（Non-steroidal antiinflammatory drugs: NSAIDs) やアセトアミノフェン, オピオイド鎮痛薬が使用される.

神経障害性疼痛=がんの神経組織への浸潤による疼痛, 化学療法誘発性神経障害性疼痛など 神経障害性疼痛は “体性感覚神経系の病変や疾患によって引き起こされる 疼痛”と定義され，がん関連の神経障害性疼痛としては 肺がんによる腕神経叢浸潤や脊椎転移による脊髄障害, さらに化学療法誘発性末梢神経障害などが該当する。神 経障害性疼痛の病態は，末梢神経終末の興奮が惹起する 侵害受容性（炎症性）疼痛とは明らかに異なるため薬物 療法の治療戦略が大きく異なる，全がん患者の約 $10 \%$ が 中等度以上の神経障害性疼痛を罹患している。その原因 


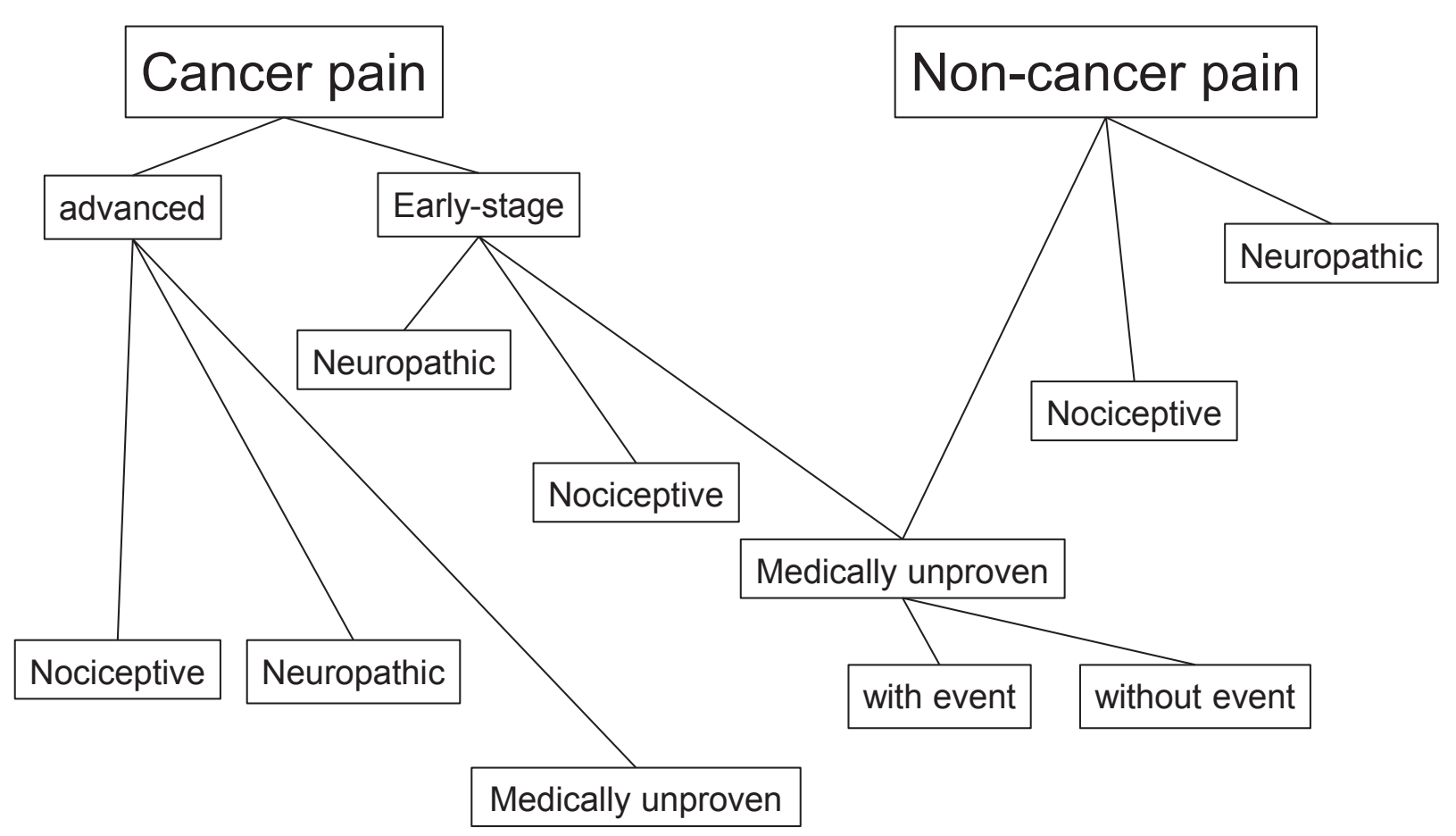

Fig. 2 Classification and categorization of pain, complained by patients

Preceding to pharmacotherapy for pain, classification and categorization of pain are needed on the basis of patients with or without cancer; underlying pathophysiological mechanisms; and prognosis of cancer patients.

はがんによる神経浸潤が約 $2 / 3$, がん治療に伴う神経障 害が約 $1 / 3$ である ${ }^{4)}$. がん治療の中ではがん化学療法に

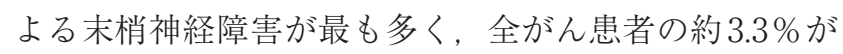
中等度以上の化学療法誘発性末梢神経障害性疼痛を罹患 している4)，神経障害性疼痛の特徵は，痛みの重症度が 高く罹病期間が長いだけでなく，感覚障害に運動障害を 伴う事があるためQOLの低下が著しいことである。神 経障害性疼痛の薬物療法については, 国際疼痛学会 ${ }^{5}$ や 日本ペインクリニック学会 ${ }^{6)}$ などから治療指針が提案さ れており，NSAIDsやアセトアミノフェンは無効で, 抗 うつ薬や抗痓攣薬に類似した薬物療法㧍よびオピオイド 鎮痛薬が推奨されている.

\section{非器質的疼痛 $=$ がん患者が抱える精神心理的問題と直結} する痛み 非器質的疼痛は身体器質的な原因を伴わない 痛みのことを指し，どのような発症メカニズムを持つか はまだ十分に明らかにされていない. 非器質的疼痛の一 例としては, うつ病患者では約 $50 \%$ が抑うつに伴って疼 痛を訴え, 腰痛や心窩部痛, 頭痛が多い5). がん患者で は30-50\%が抑うつ症状を伴っているとされ，このうち の一部のがん患者が非器質的疼痛を訴えても不思議はな い, さらに, 侵害受容性疼痛, 神経障害性疼痛, 非器質 的疼痛のいずれの病態でも, その痛みの訴えは心理社会 的要因によって修飾を受ける. 痛みの身体・精神器質因
の評価に加えて, 慢性的に痛みが継続することによって 現れる痛み以外の心理社会的要因（不眠や倦总感, 抑う つ, 不安など）とそれらによる痛みの認知・訴えの修飾 にも注目が必要である $(\text { Fig. 3 })^{6)}$. 薬物療法は精神心理 症状に応じて, 抗うつ薬や抗不安薬などの向精神薬が用 いられる。

\section{がん患者の痛み対策 - オピオイド鎮痛薬の問題点}

侵害受容性疼痛と神経障害性疼痛に対してオピオイド 鎮痛薬は最も有効性が期待できる鎮痛薬で, 積極的な適 応判断が望ましい.しかしながら, オピオイド鎮痛薬の 使用直後から発現する可能性がある嘔気や嘔吐, 便秘, 眠気などの副作用以外に，長期間にわたってオピオイド 鎮痛薬の使用を継続することによって現れる副作用があ り，そのような副作用の代表的な例がオピオイド鎮痛薬 に対する精神依存である。近年, 非がん性疼痛に対して も積極的にオピオイド鎮痛薬が使用されている北米を中 心に, オピオイド鎮痛薬の長期使用に伴って精神依存が 形成されてしまい濫用や不適切な使用による死亡例や意 識障害など重症例が増加し社会問題となっている. 特に, 痛みの治療期間が年単位になることが少なくない，がん 治療期疼痛（慢性期）とキャンサーサバイバーの痛みに 対しては, オピオイド鎮痛薬による薬物療法以外に非才 ピオイド鎮痛薬による薬物療法とともに非薬物療法を併 


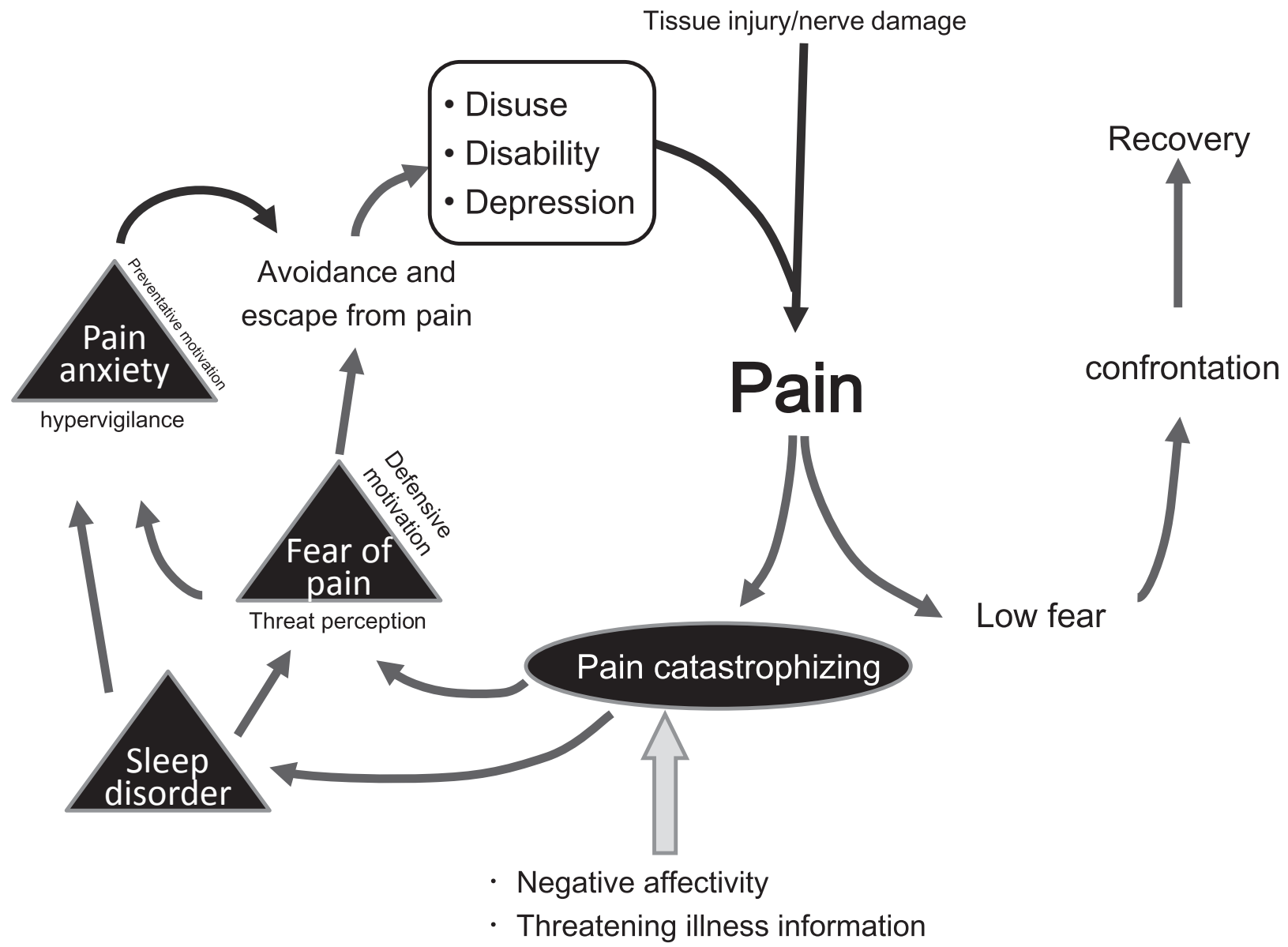

Fig. 3 Vicious cycles among pain and other negative factors modified by reference 6 Pain and its-related negative factors structure the vicious cycle.

用することが推奨されている7.

\section{がん患者の痛み対策 - 運動療法}

がん患者に対する運動療法として，(1)がん手術後の痛 みへの効果, (2)骨転移に伴う痛みへの効果, (3)がん化学 療法と放射線療法に伴う痛みへの効果が示されている.

(1)がん手術後の痛みへの運動療法の効果

頭頸部がんに対する䅡部リンパ節覚醒を伴う手術では 副神経を合併切除することがあり，これにより僧帽筋麻 痺が生じる。僧帽筋は肩甲骨の保持や肩関節の運動を支 配しているため, 頭頸部がん手術後に肩関節の痛みや一 般的に肩こりと呼ばれる筋痛を生じることがある。この ような肩甲帯の痛みや運動障害に対して, 標準的な肩関 節可動域訓練よりも筋力増強訓練を併用したほうが疼痛 の改善および上肢機能の改善が得られており筋力強化の 重要性が示されている8)。また，乳がんに対する腋窩リ ンパ節郭清後には約 $70 \%$ の患者で疼痛を伴う皮下索状 組織が生じ，肩関節の運動制限を呈する。術後の軟部組 織の癒着や癞痕組織の形成, リンパ管内の血栓形成など
が原因と考えられており自然軽快も多い一方で, 長期化 する症例や晚発化する症例があることも知られている. このような症例に対しては, 肩関節の可動域訓練やス卜 レッチング, 肩関節周囲の軟部組織の受動術が痛みの緩 和と肩関節の運動機能の改善に有効であるとする報告が ある ${ }^{9)}$. しかしながら, 乳がん患者の術後遷延性疼痛に 対する効果は未だ確立して扔らず，患者の心理社会的問 題の評価も重要である ${ }^{10)}$.

(2)骨転移に伴う痛みに対する運動療法の効果

がんの骨転移に伴う痛みは骨折リスクを評価する一つ の目安であるとともに, ADLの低下要因となる ${ }^{11)}$. 骨折 リスクを適切に評価し，場合により手術療法による骨固 定術も検討するが，骨転移のある患者に対して運動療法 を行うことで痛みの緩和やADLが改善すること，患者 満足度が高いことが示されている ${ }^{12-14)}$ 。 ただし，このよ うな骨転移に対する運動療法の有用性は脊椎転移につい てのみ調查されており，長管骨転移に対する効果は今後 の検証が必要である.

(3)がん化学療法と放射線療法に伴う痛みに対する運動療 
法の効果

がん化学療法や放射線治療に伴う運動療法が痛みや運 動機能, ADLの改善に有用であることが示されている ${ }^{15-17)}$. これらがん治療に伴う痛みは, 化学療法誘発性末梢神経 障害として呈される四肢末端の痛みや放射線照射部位局 所の痛みであるが, 有用性が示されている運動療法は有 酸素運動や筋力増強トレーニングであり全身運動による 効果である。これは筋骨格系の末梢組織への効果ではな く全身運動による中枢神経系の賦活作用や免疫系への効 果, 酸化ストレスなどが示唆されている ${ }^{18)}$ 。さらに, 運 動療法を化学療法中に併用することで化学療法により副 作用を軽減でき，がん化学療法剤の耐用量を増加できる ことも示されており, がん治療自体への有用性が期待さ れている ${ }^{19)}$

\section{がん患者の痛み対策 - 認知行動療法}

がん患者の痛みに対しては, 運動療法（リハビリテー ション）だけでなく, 認知行動療法と呼ばれる心理療法 も有用である。

がん患者に対して認知行動療法を実践する際の初期 治療目標は, 痛みの悪循環モデル（Fig. 3）に基づいて （A）疼痛強度の緩和と（B） ADLの向上の 2 つの視点 から設定する。進行・終末期のがん性疼痛に対しては疼 痛の緩和が達成されれば自動的にADLも向上しQOLが 改善することが多い. しかし，がん診断時〜支持療法期 のステージにあるがん患者やキャンサーサバイバーの慢 性化した痛みの場合には, これら 2 つの治療目標が必ず しも連動して効果が得られるわけではなく, 相乗的に作 用しあうので両方を治療対象とする重要性を診療に携わ る医療者全員が理解しておかねばならない20)。認知行動 療法は認知療法と行動療法の併用療法の総称であり, 患 者教育を実践する認知療法とともに, 行動療法として運 動療法を含む.

認知行動療法の実践にあたってはADLの向上を目標 に設定するとともに, 痛みの原因が組織傷害に伴うとい う認識（生物医学還元モデルと呼ばれる組織局所の問題 に帰結させる考え方）から，有意義な日常生活を過ごす ために治療が必要であると認識させる問題解決型の“痛 みとの付き合い方”を教育しなければならない。このよ うな患者教育は, がん末期の痛みや在宅医療での痛み管 理においても重要である事が示されている21).

さらに, 患者教育に基づいて提供される行動療法（運 動療法）では，治療開始時のがん患者の全身状態に適し た日常生活活動度の改善を初期目標として設定する。具 体的には, 現在の身体機能で行える運動（散歩, 体操な ど）や日常生活動作を繰り返すことを目標に設定し，そ れらが徐々に達成するにつれ日常生活動作に即した新し い行動内容を治療目標に追加していく，実現可能な目標
を常に立案することが治療の継続のためには重要で，段 階的に運動内容の負荷を挙げていくのが望ましい，患者 が新しい運動能力を獲得できたことを患者自身に適宜教 示し，患者が自己効力感（自分自身の問題処理能力に対 する自信）を得られるように留意し，患者が運動に対す るモチベーションを維持するように支持していかねばな らない22-24)。例えばがん性疼痛のように解剖学的・生理 学的変化を伴う病態では, 慢性的に遷延する疼痛に対す る認識の誤りだけが疼痛の原因でないことは明白である が，痛みの訴えが強いがん性疼痛患者では痛みの悪循環 が形成され，疼痛に伴う行動規範の認識が歪曲されてい ることは少なくない，よって，がん性疼痛のような身体 的障害が明白な慢性疼痛に対しても, 従来から運動療法 や認知行動療法など心理療法が有効とされている非特異 的な慢性腰痛などと同様に，薬物療法と併用することに よって患者の ADL と QOL 向上に寄与する地固め療法的 な位置付けであると考えられる。

\section{おわりに - がん患者の痛み対策の意義}

がん性疼痛の重症度はがん患者の生命予後を規定する 因子の一つである ${ }^{25)}$ 。これは，がん治療による合併症と しての痛み（化学療法誘発性ニューロパチーや放射線性 皮膚炎など）のために最適ながん治療の遂行を阻害して いることが推察されており，このような痛みへの積極的 な緩和ケア介入（薬物療法や運動療法）により生命予後 が改善することも報告されている ${ }^{26)}$. がん治療期間の長 期化とキャンサーサバイバーの増加は，がん患者とキャ ンサーサバイバーの高齢化にも直結しており，加龄性の 筋量低下が生じる。さらに，がんという全身性の消耗性 疾患による悪影響とがん治療（主に化学療法）に伴う組 織障害性による悪影響から，がん患者の筋量低下はより 顕著に生じる ${ }^{27)}$ 。筋量低下は, がん化学療法による副作 用の増悪やがん患者の生命予後の悪化と関連することが 示されている ${ }^{28)}$ ，運動療法は筋量低下を防ぐ最も重要な 治療法であり，筋量が維持されているがん患者では化学 療法による倦总感が軽症で済み，QOLが高く維持される ことが示されており，また，適切な運動習慣（1 週間あ たり 150 分以上の早歩き程度の運動）は様々ながんの発 症リスクを低減する ${ }^{29}$ 。ここような運動療法によるがん 発症リスクの低減やがん治療による副作用対策について の情報提供は，がん患者の運動療法のモチベーションと なる。

\section{利益相反自己申告}

住谷昌彦は，ファイザー製薬，塩野義製薬，日本イーライ リリー社, 久光製薬より講演料を受けた.

その他の著者は申告すべきものなし． 


\section{参考文献}

1) Thienthong S, Pratheepawanit N, Limwattananon C, Maoleekoonpairoj S, Lertsanguansinchai P, Chanvej L. Pain and quality of life of cancer patients: a mulitcenter study in Thailand. J Med Assoc Thai 89: 11201126, 2006

2) Zech DFJ, Grond S, Lynch J, Hertel D, Lehmann KA. Validation of World Health Organization guidelines for cancer pain relief: a 10-year prospective study. Pain 63: 65-76, 1995.

3) Clevenger L, Schrept A, DeGeest K, Bender D, Goodheart M, Ahmed A, Dahmoush L, Penedo F, Lucci J $3^{\text {rd }}$, Thaker PH, Mendez L, Sood AK, Slavich GM, Lutgendorf SK. Sleep disturbance, distress and quality of life in ovarian cancer patients during the first year post diagnosis. Cancer 119: 3234-3241, 2013.

4) Garcia de Paredes ML, del Moral Gonzalez F, Mrtinez del Prado P, Marti Ciriquian JL, Enrech Frances S, Cobo Dols M, Esteban Gonzarez E, Ortega Granados AL, Majem Tarruella M, Cumplido Buron JD, Gasco Hernandez A, Lopez Miranda E, Ciria Santos JP, de Castro Carpeno FJ. First evidence of oncologic neuropathic pain prevalence after screening 8615 cancer patients. Results of the On study. Ann Oncol 22: 924930, 2011.

5) Bair MJ, Robinson RL, Katon W, Kroenke K. Depression and pain comorbidity. Arch Intern Med 163: 2433-2445, 2003.

6) Leeuw M, Goossens MEJB, Linton SJ, Crombez G, Boersma K, Vlaeyen JW. The fear-avoidance model of musculoskeletal pain: Current state of scientific evidence. J Behav Med 30: 77-94, 2007.

7) Glare PA, Davies PS, Finlay E, Gulati A, Lemanne D, Moryl N, Oeffinger KC, Paice JA, Stubblefield MD, Syriala KL. Pain in cancer survivors. J Clin Oncol 32: 1739-1747, 2014.

8) McNeely ML, Parliament MB, Seikaly H, Jha N, Magee DJ, Haykowsky MJ, Courneya KS. Effect of exercise on upper extremity pain and dysfunction in head and neck cancer survivors: a randomized controlled trial. Cancer 113: 214-222, 2008.

9) Moskovitz AH, Anderson BO, Yeung RS, Byrd DR, Lawton TJ, More RE. Axillary web syndrome after axillary dissection. Am J Surg 181: 434-439, 2001.

10）鈴木愛枝, 住谷昌彦, 榎本有希, 穂積 淳, 阿部博昭, 井上 玲央, 山田芳嗣：乳がん術後遷延性疼痛による不動化の ため異なる転帰をとった 2 症例, 日本ペインクリニッ ク学会誌, 24: 60-63, 2017.

11) Mirels H. Metastatic disease in long bones. A proposed scoring system for diagnosing impending pathologic fractures. Clin Orthop Relat Res 249: 256-264, 1989.

12) McKinley WO, Conti-Wyneken AR, Vokac CW, Cifu DX. Rehabilitative functional outcome of patients with neoplastic spinal cord compression. Arch Phys Med Rehabil 77: 892-895, 1996.

13) Ruff RL, Ruff SS, Wang X. Persistent benefits of reha- bilitation on pain and life quality for nonambulatory patients with spinal epidural metastasis. $J$ Rehabil Res Dev 44: 271-278, 2007.

14) Tang V, Harvey D, Park DJ, Jiang S, Rathbone MP. Prognostic indicators in metastatic spinal cord compression: using functional independent measure and Tokuhashi scale to optimize rehabilitation planning. Spinal Cord 45: 671-677, 2007.

15) Dimeo F, Fetscher S, Lange W, Mertelsmann R, Keul J. Effects of aerobic exercise on the physical performance and incidence of treatment-related complications after high-dose chemotherapy. Blood 90: 33903394, 1997.

16) Dimeo FC, Stieglitz RD, Novelli-Fischer U, Fetscher S, Keul J. Effects of physical activity on the fatigue and psychologic status of cancer patients during chemotherapy. Cancer 85: 2273-2277, 1999.

17) Mutrie N, Campbell AM, Whyte F, McConnachie A, Emslie C, Lee L, Kearney N, Walker A, Ritchie D. Benefits of supervised group exercise program for women being treated for early stage breast cancer: pragmatic randomized controlled trial. BMJ 334: 517, 2007.

18) Markes M, Brockow T, Resch KL. Exercise for women receiving adjuvant therapy for breast cancer. Cochrane Database Syst Rev: CD005001, 2006.

19) Courneya KS, Segal RJ, Mackey JR, Gelmon K, Reid RD, Friedenreich CM, Ladha AB, Proulx C, Vallance JK, Lane K, Yasui Y, McKenzie DC. Effects of aerobic and resistance exercise in breast cancer patients receiving adjuvant chemotherapy: a multicenter randomized controlled trial. J Clin Oncol 25: 4396-4404, 2007.

20) Wittink H, Carr DB. Outcomes and effective pain treatment. Pain Clinical Updates 16: 1-4, 2008.

21) Miaskowski C, Dodd M, West C, Paul SM, Schumacher $\mathrm{K}$, Tripathy D, Koo P. The use of a responder analysis to identify differences in patient outcomes following a self-care intervention to improve cancer pain management. Pain 129: 55-63, 2007.

22) Kerns RD, Rosenberg R, Jamison RN, Caudill MA, Haythornthwaite J. Readiness to adopt a self-management approach to chronic pain: the Pain Stages of Change Questionnaire (PSOCQ). Pain 72: 227-234, 1997.

23) Kerns RD, Rosenberg R. Predicting responses to selfmanagement treatments for chronic pain: application of the pain stages of change model. Pain 84: 49-55, 2000.

24) Jensen MP, Nielson WR, Romano JM, Hill ML, Turner JA. Further evaluation of the pain stages of change questionnaire: is the transtheoretical model of change useful for patients with chronic pain? Pain 86: 255-264, 2000.

25) Reyes-Gibby CC, Anderson KO, Merriman KW, Todd KH, Shete SS, Hanna EY. Survival patterns in squamous cell carcinoma of the head and neck: pain as an independent prognostic factor for survival. J Pain 15: 1015-1022, 2014. 
26) Temel JS, Greer JA, Muzikansky A, Gallagher ER, Admane S, Jackson VA, Dahlin CM, Blinderman CD, Jacobsen J, Pirl WF, Billings JA, Lynch TJ. Early palliative care for patients with metastatic non-small-cell lung cancer. $N$ Engl J Med 363: 733-742, 2010.

27) Buford TW, Anton SD, Judge AR, Marzetti E, Wohlgemuth SE, Carter CS, Leeuwenburgh C, Pahor M, Manini TM. Models of accelerated sarcopenia: critical pieces for solving the puzzle of age-related muscle atrophy. Ageing Res Rev 9: 369-383, 2010.

28) Christensen JF, Jones LW, Andersen JL, Daugaard G, Rorth M, Hojman P. Muscle dysfunction in cancer pa- tients. Ann Oncol 25: 947-958, 2014.

29) Moore SC, Lee IM, Weiderpass E, Campbell PT, Sampson JN, Kitahara CM, Keadle SK, Arem H, Berrington de Gonzalez A, Hartge P, Adami HO, Blair CK, Borch KB, Boyd E, Check DP, Fournier A, Freedman ND, Gunter M, Johanson M, Khaw KT, Linet MS, Orsini N, Park Y, Riboli E, Robien K, Schairer C, Sesso H, Spriggs M, Van Dusen R, Wolk A, Matthews CE, Patel AV. Association of leisure-time physical activity with risk of 26 types of cancer in 1.44 million adults. JAMA Intern Med 176: 816-825, 2016. 